\title{
Bringing Grievances Back In
}

\section{Towards an Alternative Understanding of the Rise of the Moro Islamic}

\section{Liberation Front in the Philippines}

\author{
Jeroen Adam \\ Conflict Research Group, Faculty of Political and Social Sciences, \\ Ghent University \\ jeroen.adam@ugent.be
}

\begin{abstract}
Over the past 10 to 15 years a pertinent critique has been formulated against the dominant framing of violent conflict in Muslim Mindanao as a mere struggle for autonomy or independence by a Muslim minority against the Philippine nation-state. This critique demonstrates how a wide range of coercive organizations compete over gaining access to rents, and how this competition is the main source of violent incidents. Furthermore, it is discussed how this violent competition over rent access has a clear subnational, intra-Muslim character. This article argues that, despite its obvious merits, this literature has come to overestimate the greed-related features of contemporary conflict in Muslim Mindanao and the coercive qualities in the build-up of political authority in the region. As an alternative, we wish to bring grievances and ideology back in, allowing for a more nuanced understanding of conflict and politics in the region. This will be done by illustrating how the spread of the Moro Islamic Liberation Front (MILF) as a legitimate and morally just alternative against injustices and inequalities within Muslim society has been crucial to the organization's extraordinary growth in recent decades.
\end{abstract}

\section{Keywords}

Philippines - Moro Islamic Liberation Front - grievances - warlords - civil society third-party mediation 


\section{Introduction}

From the late sixties onwards, when Muslim and Christian militia groups started clashing over issues of land control and electoral politics, the western and central parts of the Philippine island of Mindanao have been witnessing one of the longest-running armed conflicts in the world. Traditionally, accounts about the emergence of this conflict point to the political and economic marginalization of a minority Muslim community in a Christiandominated Philippine nation-state. The Moro National Liberation Front (MNLF) and, at a later stage, the Moro Islamic Liberation Front (MILF), are hereby understood as the main representatives of this minority Muslim population, translating these grievances into an armed struggle for independence/ autonomy (Che Man 1990; Taya 2007; Tuminez 2007). Within these classic accounts, a parallel is also being drawn between a colonial and a post-colonial context. It is argued that the Muslim minority's resistance against the colonial project of the Spaniards and the Americans simply continued after Philippine independence, but was now redirected against 'imperial' Manila.

In recent decades, two important nuances have been formulated against this traditional narrative. First, elaborate historical analyses, in particular by Abinales (2000, 2010) and Mc Kenna (1998), have provided a systematic critique on what they label as the myth of an eternal and unified Muslim resistance. In contrast to this myth, these authors point to the great level of accommodation of, and collaboration among, Muslim elites with the projects of colonial and post-colonial state-building. As poignantly argued by Abinales (2000:46), with the expansion of state bureaucracy - in particular from the American period onwards-Muslim elites increasingly shifted their traditional focus away from the sea (as maritime trading elites) and towards Manila (as emerging colonial politicos). Importantly, the emergence of the MNLF in the early seventies can therefore no longer be seen as a mere logical continuation of resistance against the colonial oppressor. Rather, the MNLF came into existence as a response to the brutality of the Marcos regime and the manner in which Christian militias displaced thousands of Muslim households in the late sixties. In addition, the emergence of the MNLF needs to be understood as a reaction of young, male Muslims to the close identification of Muslim elites and politicians with the Philippine nation-state.

Second, apart from this historical critique on the narrative of eternal resistance, in the past 10 to 15 years another important body of literature has emerged. This literature-which constitutes the analytical starting point of this article-departs from the dominant view that conflict in Muslim Mindanao can be solely explained by reference to the historical grievances of the 
minority population. It thereby stresses the manifold, often localized roots of most of the violence in Mindanao, and, subsequently, points at the multiplicity of violent actors and organizations. A number of publications have been pivotal within this transition. One of the first studies was presented by an American NGO, The Asia Foundation. This study demonstrated that violence in Mindanao could no longer be merely understood as a national, horizontal conflict; simultaneously — and maybe even more importantly—a vertical, subnational conflict was taking place (Torres 2007). Within this research project, this subnational conflict was mainly understood as one of intra-Muslim clanconflict, or so-called rido. At a later stage, these findings were further refined in a World Bank-funded dataset called the 'Bangsamoro Conflict Monitoring System' (International Alert 2014). Particularly relevant for our argument here is that what is being labelled within this database as 'political issues' or a classic, national, vertical conflict between armed insurgents and the Philippine army accounts by and large for $25 \%$ of all violent incidents that occurred in the period 2012-2014. The largest cause of violence is here understood as competition over access to the informal economy, including drugs, weapons, and an informal land market.

These emerging insights about the causes of violent incidents in Muslim Mindanao coincided with a growing awareness of the multiplicity of violent actors in the region and their different identity labels (Adam 2013). While in more traditional accounts the focus was on 'classic' rebel groups such as the MNLF and the MILF, the new literature demanded attention for a multiplicity of armed organizations and actors - including paramilitary organizations, private armies, the police force, and armed actors whose flexibility allowed them to switch allegiance between classic 'rebel groups' and state-mandated coercive organizations (Verbrugge and Adam 2016). In addition, the concept of the 'clan' clearly entered the limelight as a defining, kin-based and coercive organization. Considerable attention has therefore been paid to the clan leaders, who are understood as strongmen-politicians and are often highly authoritarian, embodying, as they do, both traditional and coercive forms of authority. As an illustration of this trend, we refer to two authors in particular. First, there is the work by the German political scientist Peter Kreuzer, who explicitly approaches powerful local clans as 'agents of violence' (Kreuzer 2005:3). Kreuzer notes how an analysis of violence in Mindanao should go beyond a framework that merely points to the historical marginalization of the Muslim community. In addition, Kreuzer also stresses how the capacity for violence/coercion cannot be entirely focused on classic rebel groups and how this risks disguising a much deeper issue. As stated by Kreuzer (2005:11): 'Clan policy is central to understanding the microdynamics of civil war, which, on the sur- 
face, presents itself as a rebellion of Muslims against a Christian state.' Albeit within a different theoretical framework, a similar preoccupation runs through a book by the Philippine scholar Francisco Lara (2014). In this book, which is fittingly titled Insurgents, clans and states, Lara pays attention to the manner in which strongmen-politicians attempt to maintain their position in a volatile socio-political landscape. The focus is hereby explicitly on elites, as these are considered to 'have the resources to make or break a state (to fund a private army or support a political military organization)' (Lara 2014:xv). Lara explains how clan institutions have systematically interacted with other political institutions, including rebel organizations. Importantly, Lara also considers a classic narrative about the historical injustices against the Muslim population as inadequate to account for the ongoing violence in this region. As stated in a previous publication, 'a gap exists in current analysis of persistent conflict in Mindanao, which is based upon a traditional discourse of exclusion that fails to capture the region's shifting economic and political conditions' (Lara and Champain 2009:6).

We welcome this change in the focus of the literature. The observation that the overall conflict ecology in Mindanao is fragmented among a range of coercive organizations and that the causes of violence cannot be narrowed down to one meta-narrative about historical grievances is supported by conclusive quantitative and qualitative evidence. Yet, despite its obvious merits, we also wish to point at two major deficiencies. First, because of its strong focus on powerful elites and clans, the political agency of subaltern populations tends to be underrated and neglected. Too often, an implicit picture is painted of these subaltern populations as being passive victims stuck in feudal and oppressive relationships. While this may be true in some cases, we would like to start our analysis from a different angle. This is the simple observation that many of the people in Muslim Mindanao are highly critical about the manner powerful clans and their respective leaders maintain their elite position through exploitative and coercive arrangements. As such, this article follows the argument from Nathan Quimpo (2005) that Philippine socio-political history too often has been misrepresented as a top-down narrative of elites, bosses, or strongmen (see Anderson 1988; Sidel 1999) and that the manner in which agency 'from below' has been constitutive of this history has too often been underrated. The argument that we will put forward is that these grievances about the elitist characteristics of the regional political landscape in Muslim Mindanao are one of the prime explanations for the spectacular growth of the MILF in recent decades. Through a specific religious discourse stressing equality, purity, and morality, the MILF has profiled itself as a legitimate alternative against a socio-political landscape which is considered as feudal, immoral, and 
elitist. This leads us to our second point, which is that too many of the writings on Muslim Mindanao have been obsessed by a quest to uncover the reasons and motivations behind the emergence of violence. Also in this case, we would like to start our analysis from a systematically overlooked observation, namely that the MILF, as the most important organization representing the Muslim minority population in the Philippines, is much more than just an armed rebel movement. Rather, it is a complex and multi-faceted mass organization, offering a wide range of social activities, working with a wide range of social groups, and having a strong and dynamic connection with a broad civil-society movement. By constantly delving into the reasons why people engage-or do not engage-in violent conflict, a broad spectrum of political and social engagement is being overlooked that has been crucial for the growth of the MILF during recent decades. It is exactly this group of civil-society activists we wish to draw attention to by unravelling some of the rationalities for their nonviolent political engagement with an organization such as the MILF. We will empirically substantiate the arguments made above by studying how one cso (civil-society organization) called United Youth for Peace and Developemnt (UNYPAD) UNYPAD has been involved in initiatives of reconciliation, conflict management, and peace building. After presenting an analysis about the way in which UNYPAD is involved in these interventions, we will further elaborate on some of the analytical consequences of our empirical observations. ${ }^{1}$

\section{The Moro Islamic Liberation Front: A Short Background}

As indicated, 'the conflict' in Mindanao started—by and large —in the late sixties, when loosely organized Christian and Muslim militias started clashing with each other (Mc Kenna 1998). After the promulgation of martial law in 1972, these Muslim militias crystallized into one large organization called the MNLF. In subsequent years, high-intensity armed conflict erupted between the Marcos regime and the MNLF. Due to the large losses suffered by both sides, and under pressure from the Organization of the Islamic Conference (OIC), an uneasy peace agreement was signed in 1976, known as the Tripoli Agreement. One of the reasons behind the creation of the MILF was dissatisfaction with this Tripoli Peace Agreement. Due to the lack of commitment by

1 The data for this article were collected between 2012 and 2015, during which time, over a total period of nine months, different initiatives of conflict management and reconciliation in the provinces of Maguindanao, North Cotabato, and Lanao del Sur were systematically studied through semi-structured interviews and participant observation. 
subsequent administrations to implement the main provisions of the agreement, a considerable part of the MNLF broke away under the leadership of the Al-Azhar graduate Hashim Salamat. Importantly, this rift is also rooted in a discord between a more Islamist inspired faction led by Salamat and a more secular/leftist inspired faction led by Nur Misuari. While somewhat remaining under the radar throughout the eighties, it was particularly in the nineties that the MILF managed to overtake the MNLF as the most important Muslim oppositionist movement on mainland Mindanao. An important signifier of this transition was the instalment of MNLF leader Nur Misuari as governor of the Autonomous Region of Muslim Mindanao (ARMM) in 1996. While on the one hand symbolizing the ultimate rise to power on the part of the MNLF, this period, during which Misuari acted as governor of the ARMM, also came to be remembered as a period rife with corruption and mismanagement, during which the MNLF and the ARMM did not manage to live up to their promises (Bertrand 2000; Lara 2014:61). As such, one witnessed a transition wherein the MILF came to position themselves as the main representatives of the Muslim minority population in the Philippines, thereby overruling the MNLF.

As the MILF was gaining in strength and popularity and a final peace agreement was ultimately reached with the MNLF, the MILF and the Philippine government entered into a somewhat uneasy liaison dangereuse from the late nineties onwards, wherein periods of rapprochement alternated with periods of intense armed confrontation. In 1997, the first talks about installing some preliminary ceasefire mechanisms were opened with the MILF, resulting in the establishment of the Coordinating Commission on the Cessation of Hostilities ( $\mathrm{CCCH}$ ) and, at a later stage, the Ad Hoc Joint Action Group (AHJAG). These mechanisms, however, did not prevent the MILF and the Philippine government from engaging in heavily armed confrontation in 2000, when the most important military camp of the MILF, camp Abu Bakr, was overrun by the Armed Forces of the Philippines (AFP). Similar armed encounters occurred in 2003, 2005, and 2008. After the installation of the Aquino administration in 2010, the MILF and the Philippine government entered a new round of intensive peace negotiations, resulting in the signing of the Framework Agreement on the Bangsamoro (FAB) in 2012. One of the most important statements in the FAB was the formal commitment to replace the existing ARMM with the Bangsamoro (Moro/Muslim nation), and that this Bangsamoro would be governed by a Bangsamoro Basic Law (BBL). This FAB served as the foundational document for the Comprehensive Agreement on the Bangsamoro, which was signed in 2014 and then served as the blueprint for the final ввL. This ввL was released by the Bangsamoro Transition Commission in September 2014, after which it was meant to be ratified by the 
Philippine congress and senate. Yet, very quickly, this в вL became subject to close, critical scrutiny and public debate. This became the case even more so when, on 25 January 2015, a poorly planned intervention by the SAF (Special Action Force) to hunt down two terrorists accidently ran into a MILF camp, resulting in 44 SAF police officers being killed in the armed encounter that ensued. This incident turned the public mood into one of overt hostility against the MILF, and proved to be a major blow for the whole peace process. Ultimately, the Aquino administration came to an end in 2016 without having secured a legally binding peace accord with the MILF. The new Duterte administration, which was inaugurated in June 2016, has formally pledged to continue the ongoing peace talks, albeit in a new institutional setting which leaves more room for non-MILF representatives. At present, it is difficult to predict the manner in which the whole peace process will continue, apart from by noting that the current Duterte administration has made a clear commitment to bringing the ongoing talks with the MILF to a successful conclusion.

\section{An Alternative Approach Towards the MILF}

Despite being the largest Muslim organization on mainland Mindanao and being the main protagonist in a long process of peace negotiations with the Philippine government for the past two decades, the MILF's origins, internal organization, and ideological platform(s) remain remarkably unclear. On the one hand, there exists a stream of literature written by people sympathetic to, or closely involved in, the movement (Mastura, 2012; Jubair 1999, 2007). This literature should mainly be understood as a further exponent of the classic historical grievance thesis in which a straight line is drawn from Spanish colonialism to American colonialism to the independent Philippine nation-state. For instance, Jubair (1999:128) speaks explicitly about the Muslims falling into the 'hands of the neo-colonial Filipino rulers', resulting in a further deterioration of the rights of the Muslim minority when compared to the American colonial period. Furthermore, because of their insiders' view, these publications provide interesting and relevant historical background and detail about the manner in which the MILF split off from the original MNLF, and about how negotiations were being conducted with the Philippine government. Yet, a truly academic and more distant assessment is too often lacking. On the other hand, there exists a set of articles and book chapters that provides relevant, yet also fragmented and incomplete data about this movement (Abuza 2005; Mc Kenna 1998; Abinales, 2010). 
One of the most crucial insights that emerges out of this literature is the call for a relational understanding of the MILF. This relational approach is intimately connected with some of the new insights into the conflict landscape in Mindanao that have been described above. As 'the conflict' can no longer be understood as just a conflict about autonomy/independence, the MILF can also no longer be understood as a rebel movement simply struggling for autonomy/independence. Instead, attention is paid to the manner in which different types of (coercive) authority and different rationales for violence interact with each other. It is argued that the MILF cannot be understood as a homogeneous and unitary movement, operating independently from the existing centres of authority in the region. Moreover, the supposed boundary between insiders (MILF) and outsiders (non-MILF) cannot always be easily drawn. Within these accounts, the rise of the MILF as a mass movement can only be explained through the establishment of critical alliances with existing strongmen/clan leaders, providing the MILF with considerable coercive capacity (Abinales 2010:124; Lara 2014:68-9). As a result, it has been argued that the authority the MILF is exerting in multiple places in Mindanao can only be understood as a form of mediated governance (Verbrugge and Adam 2016). The relationship between the central leadership of the MILF and these more decentralized centres of authority and coercion has always been a strained one, marked by pragmatic calculations; the central leadership recurrently struggles to maintain a degree of control over some of these local commanders (Kreuzer 2005; Podder 2012:504). Indeed, there are regular instances of MILF commanders and their respective followers clashing with each other, often over access to vital economic resources (Cabrera 2014; Unson 2014). One therefore always needs to maintain a critical distance when people are identified as 'MILF commanders' or 'MILF fighters', as many of these commanders/fighters display varying allegiances to different political authorities. The same is true for those areas designated as 'MILF territory' or 'MILF strongholds'. These tend to be imagined as places that are foremost defined by their 'statelessness' and wherein the MILF is the sole and only public authority. This idea rests on a false dichotomy, wherein 'the state' and 'the MILF' are falsely understood as two opposing entities. As argued above, a specific, relational understanding of the MILF discourages representations that put forward these types of neat and separate categories. Rather, people and organizations navigate within a complex socio-political landscape and dynamically switch hats and identities. This has already been seen in the flexibility that is displayed whereby individuals switch between different types of coercive organizations, some of which have a clear state-like, formal character. It is also not uncommon for rebel fighters to be simultaneously employed as civil servants (at the end of the day, one 
needs to have an income) or for a certain politician to be widely known to be an MILF or MNLF sympathizer. Moreover, rather than the MILF eliminating statist institutions, the strength of the MILF is often measured by the degree to which it manages to penetrate the local state. For instance, the barangay (village) of Luanan (in the municipality of Aleosan, in the province of North Cotabato), was described by residents and non-residents alike as a true 'MILF stronghold'. Interestingly, when elaborating on what this meant, it was stated that 'even the barangay captain is a member of the political committee of the MILF. In this barangay, most of the people here are MILF.' The strength of the MILF is therefore not understood as 'overruling' the state or statist institutions; rather, it is explained through its strong symbiosis with the state and statist institutions. Importantly, all of this should not necessarily be seen as some sort of evidence that the MILF is a 'weak', disorganized, or fractured organization, or an organization that does not have the necessary capacity to replace or annihilate the Philippine state. Instead, this should be understood as proof of the MILF's exceptional capacity to navigate between different institutional spheres and to build up temporary but necessary alliances.

As our analysis below will demonstrate, all these observations are largely correct. However, they risk downplaying the diverging rationales that people have (or don't have) to engage with the MILF. Too often, the implicit explanation is that 'ordinary' people are simply following their leaders based on an uneven, clientelistic relationship, rooted in kinship connections, wherein control over coercive resources is pivotal to the build-up of public authority. Closely related to this observation is the fact that too often a multifaceted organization such as the MILF has been approached as a mere rebel movement, defined above all by its armed capacity. Yet, this narrow representation of the MILF as just another armed and elite-dominated organization in Mindanao is unable to account for the remarkable growth and success of this movement over the past 30 years. In order to adequately explain this formidable achievement, we need to alter our viewpoint, away from the elites towards the grassroots, and away from coercive authority towards soft power, ideology, and everyday social interactions.

As a starting point for this exercise, we will attempt to understand how the MILF, in a strategic partnership with a wide array of civil-society organizations, has attempted to profile itself as a capable conflict mediator, and, in this case, as able to reconcile warring clans. We explicitly approach these interventions

2 Personal communication with Focus Group Discussion (FGD) political leaders, barangay Luanan, Cotabato City, 3-9-2014. 
in a procedural manner as occasions during which strategic alliances are negotiated and power relations redefined, and different actors and organizations are able to see opportunities to enhance their legitimacy. Obviously, this arena of dispute settlement and reconciliation is only one of many arenas of governance in which the MILF and affiliated csos are active. We will therefore broaden our analysis after this first part by looking at some of the other governance activities the MILF is involved in.

\section{Dispute Settlement and the Build-Up of Political Legitimacy}

Any analysis about the involvement of the MILF in initiatives of dispute settlement and reconciliation should take the above-mentioned arguments as a starting point. This implies that, strictly speaking, there is not one unified organization called the MILF. However, as most of the analysis so far has focused on the interaction between the central leadership of the MILF and existing centres of coercive authority in the countryside, we would like to include another crucial group that has been systematically overlooked. This is a group of unarmed csos. Based on an analysis of a range of conflict management interventions in the region between 2013 and 2015, three different social groups can be distinguished that are active in these initiatives. In the remainder of this article, we will refer to these as 1) the 'core' MILF, or the central leadership and top commanders within the Bangsamoro Islamic Armed Forces (BIAF), but also in the $\mathrm{CCCH}$ and AHJAG; 2) a diverse set of local strongmen/MILF commanders, who pay varying degrees of allegiance and loyalty to this core MILF but above all are tied to a socio-political landscape defined by kinship affiliation; and 3) a group of csos. The main characteristic of this last group is that it consists of 'ordinary' citizens who play no direct role in the military organization of the MILF. These ordinary citizens can both be formal members of the MILF, or people/organizations working in the orbit of the core MILF in a more hidden manner. In this article, we will particularly discuss the position, discourse, and strategies of one organization: UNYPAD. UNYPAD was established in 2004 and is an organization that is nationally structured with chapters at the national, provincial, municipal, and barangay levels. Yet, despite this specific structure, UNYPAD's activities focus primarily on Muslim Mindanao, with their main office being situated in the city of Cotabato. The organization defines itself quite broadly as an NGO working for a 'prosperous and peaceful society [which] champions a just and holistic approach to developments.' ${ }^{3}$ However, upon closer scrutiny, the main

3 http://unypad.org/aboutus/our-vision/ (accessed 24-04-2017). 
activities of the organization can largely be divided into three different types. First, there is a set of relief operations that follow natural disasters, such as typhoons, earthquakes, and floods, but which also include interventions coping with displacement following armed conflict. These activities have been funded (among other) by donors as diverse as the Food and Agricultural Organization (FAO), the EU, UNICEF, UNDP, Save the Children, and the Lutheran World Relief. This impressive list not only serves as evidence of the organizational capacity of UNYPAD, but also shows how UNYPAD has managed to develop extensive networks in the world of international donor agencies. Interestingly, because of the close interaction between UNYPAD and the MILF, UNYPAD has come to serve as a crucial organization, building up pivotal linkages with the international donor community for the MILF. A good relationship with donors is something that the core leadership of the MILF has deliberately aimed for over the past 15 years, in a bid to enhance their legitimacy as a serious and internationally respected organization. In addition, these relief operations have added to the popularity of the MILF and affiliated csos such as UNYPAD. Secondly, apart from coordinating these relief operations, UNYPAD not only functions as a reservoir of future leaders for Muslim Mindanao, but also for the MILF in particular. With this role in mind, key members follow regular leadership training programmes, among others organized by The Asia Foundation (TAF) and the Japanese International Cooperation Agency (JICA). Thirdly, the organization is involved in peacebuilding and conflict-monitoring/management interventions. One of the most important activities is their role in monitoring the ceasefire mechanisms between the Philippine government and the MILF. They have also been one of the most prominent NGOs working in partnership with The Asia Foundation, an American NGO, on programmes aimed at conflict management and the reconciliation of local-level disputes. It was within one of these programmes that the intervention we discuss below took place.

An illustration of the interaction between these three different social groups (core MILF, local commanders, and csos) could be seen when analysing a conflict management intervention in the barangay of Gayonga, in the municipality of northern Kabuntulan, in the province of Maguidanao. ${ }^{4}$ In this barangay, tensions developed between two families called Luna and Samson (The Asia Foundation 2010). These tensions started after Abdila Samson was killed on 1 January 2010, around 1 pm, as he was on his way home after a New Year's celebration.

4 Data were retrieved using a combination of oral history and FGDs, both with the parties involved in the conflict and the actors/organizations engaged in the conflict management interventions. For reasons of security, we have decided not to give detailed information about the informants. 
The reason for the killing was the alleged stealing of construction materials. Soon after this incident, Kali Salig, identifying himself as an MILF commander, publicly declared he was intent on avenging the murder of his cousin. Further aggravating this situation, the brother of the murder victim allegedly attempted to rape a female member of the Luna family a couple of days after the murder. Although no clear evidence was produced linking the murder of Abdila Samson to the Luna family, rumours were rife that the perpetrators of the killing were to be found among that family, as a serious public fight had occurred some years before, following a billiards match between Abdila Samson and a member of the Luna family. All this considerably aggravated the overall situation, which by many was considered as prone to quick escalation. Out of fear of retaliation, members of both families living in the vicinity of each other abandoned their houses and any contact was firmly avoided. In addition, the involvement of MILF commanders and their respective followers gravely worsened the overall situation. As indicated, Kali Salig publicly declared his allegiance to the Samson family, while another MILF commander, named Lemon Tree, was understood to be closely aligned to the Luna family (The Asia Foundation 2010).

These instances, where disputes of various sorts have a potential for violent escalation, are commonplace across the region. As such, this case study needs to be understood as illustrative of the relatively prominent type of intraMuslim dispute that occurs at the subnational level of the conflict. For our purposes here, there are two important observations. First, a dispute such as the one that took place in Gayonga serves as a concrete illustration of the networked nature of an organization such as the MILF. Certain commanders who have pledged allegiance to the MILF-and who can be recruited in critical instances as a fighting force against the Philippine state-also deploy their coercive capacity in a range of localized tensions. In general, the specific escalation that can be witnessed here is one based on kinship affiliation. This potentially pits MILF commanders and their respective followers against each other. This brings us to a second observation, and this concerns the manner in which the core leadership of the MILF attempts to deal with these situations, which clearly are bad for the image of the MILF. As the core leadership of the MILF is aware that these local commanders have control over the large majority of the MILF's foot soldiers, cases in which these commanders are being extradited from the MILF are rare. Instead, a subtle mix of consultation and coercion, whereby these local disputes are settled through third-party mediation, is preferred. It is in such situations that a group of affiliated csos becomes involved. In the case of the above-mentioned conflict between the Samson and Luna families, it was UNYPAD that initiated the process of third-party mediation. This particular UNYPAD chapter in the municipality of northern Kabuntalan was 
established in 2008 to provide relief assistance for Internally Displaced Persons (IDPS) after heavy fighting broke out between a renegade MILF commander by the name of Umbra Katho and the Philippine army. ${ }^{5}$ The total membership of this UNYPAD chapter added up to 31, with a clear majority of male members, including in all the leading positions. Interestingly, the members of this UNYPAD chapter mentioned that they only started the process of third-party mediation once these MILF commanders had openly stated their allegiance to the conflicting clans. At that point they decided to install a network of religious leaders and civil-society activists, who coordinated talks between the appointed representatives of the conflicting families.

In contrast to some other instances of third-party mediation, this case was pushed through remarkably fast. After three appointees (including the aforementioned M ILF commanders) had been nominated as spokespersons for their respective clans in consultation, two joint sessions of consultation and deliberation were organized. Ultimately, these negotiations resulted in the signing of a peace covenant on 14 April wherein both families pledged that they would refrain from using any further violence. Remarkably, within this so-called community peace covenant there is no mention whatsoever of any form of compensation money for the actual murder. In most other cases that have been documented, this process of third-party mediation resulted in the payment of an agreed amount of compensation, locally referred to as 'blood money'. On 27 April, a large public event (kanduli) was organized wherein both clans publicly stated their allegiance to the agreement. This event was attended by a large audience and members of the Philippine National Police (PNP), Armed Forces of the Philippines (AFP), the mayor of northern Kabuntalan, and an official delegation of the MILF. Ultimately, from the moment that UNYPAD decided to establish a mechanism for third-party mediation (25 March) and the final public ceremony (27 April), only one month had passed.

Obviously, some legitimate concerns can be put forward about the manner in which this process has been concluded. As close relatives of the murdered victim Abdila Samson indicated, the whole settlement felt very much as an imposed one and multiple questions remain about the reasons behind the murder, the veracity of many of the rumours still circulating, and the identity of the

5 These violent clashes need to be understood against the background of failed peace negotiations between the MILF and the Philippine government around that time. Due to these failed negotiations, a section of the MILF under the leadership of Umbra Katho split off from the main organization. This splinter group ultimately proved to be the beginning of a new rebel movement in the region, known as the Bangsamoro Islamic Freedom Fighters (BIFF). This organization continues its violent battle for a totally independent, Muslim homeland today. 
perpetrators. Also, frustration existed that there was no mention of any form of compensation for the murder of Abdila Samson. According to close relatives of the murder victim, this was due to their inferior status in the community, meaning that they were obliged to 'submit to the authorities, whatever was agreed'. Members of UNYPAD confirmed that there was no conclusive evidence linking the Luna family to the murder of Abdila Samson. However, from their viewpoint, once certain rumours were believed to be true, they were forced to intervene in a decisive manner in order to avoid any further escalation. However, rather than providing an assessment of the sustainability or righteousness of these interventions, what interests us foremost are the political dynamics at play. To begin to analyse these, it is necessary to take a closer look at the pivotal role played by an organization such as UNYPAD.

As explained, there is a delicate balancing act between the core MILF, constituting a central leadership, and the group of regional strongmen whose loyalty towards the MILF is much more ambiguous. As the MILF is very much dependent on the coercive capacity of these peripheral leaders, its central leadership has always attempted to incorporate these structures into their organization. On the other hand, these local commanders have always maintained a strategic distance from the MILF. Most important of all, this core leadership tries to avoid direct confrontations with these local commanders. Therefore, a subtle strategy needs to be developed to tie these commanders to the organization. Crucial in this regard is the observation that any attempt at a settlement in localized disputes requires a certain organization to act as a neutral third party, mediating between the conflicting clans. In many cases, it is at this point that a CSO such as UNYPAD or a similar organization emerges as a crucial party. Interestingly enough, when discussing this intervention-and many other similar interventions - with members of UNYPAD it became clear that a dual agenda could be discerned. First, the rationale behind these interventions followed some sort of classic pro-peace agenda, in the sense that interventions were guided by a strong belief in the desirability of a peaceful conclusion to these types of disputes. On a second level, however, it was clear that this pro-peace agenda could not be separated from a deep conviction that the MILF needed to be supported in their project to become a credible and legitimate governance actor, among others through the provision of security. As mentioned by Rahib Kudto, UNYPAD's national president: 'MILF is actually a legitimate revolutionary organization mandated by the people. But it's still not legitimate enough to act as a security provider for our people. ${ }^{6}$ It is with this objective

6 Interview with the national president, secretary general, and national vice-president for internal affairs of UNYPAD, 7-2-2014, Cotabato City. 
in mind-enhancing the capacity of the MILF to act as a legitimate security provider-that a tactical alliance emerged between UNYPAD and the core MILF. This 'tactical alliance' does not have to be understood as one consisting of hidden backroom deals. Rather, one notices here how two groups have a shared agenda, not only in wanting to end this feud in an 'elegant' manner, but also in wanting to profile the MILF as a credible governance actor capable of settling violent disputes.

\section{Muslim Civil Society and the MILF}

This analysis of a particular conflict management intervention brings to the fore a type of unarmed civil-society actor that has so far remained invisible within the classic representations of Muslim Mindanao as a wild place dominated by coercive forms of (male) authority. Whilst coercion - as in many other places in the world-is definitely an important characteristic of the political landscape in the region, this does not mean that other societal organizations that have no coercive means do not have the capacity to strategically manoeuvre themselves within this landscape. Interestingly enough, in the case above and in many other cases of conflict management and reconciliation, the position of an organization such as UNYPAD is one of deliberate invisibility. Profiling themselves as a neutral organization, through whom negotiations between the disputing parties are facilitated, at first sight, their role is a passive one. However, it is exactly their position as invisible brokers that makes these organizations indispensable in these initiatives, and a crucial ally of the MILF central leadership.

Obviously, conflict management and reconciliation are only one of a wide range of governance arenas in which this proactive involvement of a MILFaffiliated civil society can be witnessed. As a further indication of how these csos have been crucial in building up legitimate authority for the MILF, we will refer to the recent history of the municipality of Midsayap, in the province of North Cotabato. As described by Verbrugge and Adam (2016), throughout the 1980s and 199os this municipality was subject to intense periods of warfare between rivalling clan leaders/warlords. One of the major incentives for these violent clashes was control over state patronage funds at the municipal and village (barangay) level, which had increased considerably after the implementation of the 1991 Local Government Code. Interestingly, despite this history of violent clashes and vivid memories about the brutality of some of these strongmen/politicians, there existed a general agreement among the residents of the municipality that, from the mid 2000 s onwards, a gradual but 
notable improvement could be observed in the overall peace-and-order situation. ${ }^{7}$ Obviously, the reasons for this transformation are diverse. Yet, our data clearly point to a considerable increase in the coercive capacity and-and probably more importantly-social legitimacy of the MILF as the prime explanation for the reduction of intra-Muslim violence. Within this transformation, the 'core MILF' has managed to reinforce their control over unpredictable, socalled loose, commanders and the power balance has shifted towards this core MILF.

In instances where violent disputes erupted between rivalling MILF commanders, a more active intervention of BIAF forces stationed at camp Darapanan was noted. Also, pressure was put on local commanders/politicians to stop, or at least curb, extortion practices, which were very common at that time and which mainly comprised of exploitative sharecropping agreements. ${ }^{8}$ Without any doubt, the capacity of this core MILF went hand in hand with the establishment of organizations such as the $\mathrm{CCCH}$ and the AHJAG. These organizations need to be understood as state-mandated institutions that acknowledge the MILF as a legitimate security provider. As such, these have helped the central leadership of the MILF to build up symbolic state and coercive authority that clearly transcends divisive clan politics. However, this is only one part of the story. This increase in state-mandated coercive capacity by this core MILF cannot be understood without taking into account the crucial role played by Bangsamoro's proactive civil society. First of all, in a similar manner as described for the Luna versus Samson dispute above, these csos took up a position of deliberate neutrality and distance vis-à-vis rivalling and conflicting clans. As such, they managed to act as a neutral institutional venue through which different disputes could be settled. In the meantime, they maintained vital links with the 'core MILF' and local MILF political committees. Also in this case UNYPAD was one of the prime organizations through which conflict management interventions were deployed. A deliberate policy was hereby installed by UNYPAD wherein their Quick Response Team (QRT) QRT members were obliged to remain non-partisan during election periods. Once again, there were careful and ongoing deliberations with different barangay captains during which it was stressed by the UNYPAD leadership that their members could never become vassals of the local politicians, otherwise they would simply lose their relevance as neutral venues of conflict management.

7 Interviews with Maks Mangadta, member of the Mindanao Human Rights Action Committee (MINHRAC), 28-1-2014, Cotabato City, and with Anwar Saluwang (UNYPAD member), 31-12014, Cotabato City.

8 FGD UNYPAD community organizers, 12-3-2013, Midsayap. 
This loose but strategic coalition between this Bangsamoro civil society and the core MILF leadership is not coincidental. Rather, it is founded upon the UNYPAD leadership's conviction that, ultimately, the MILF is the only credible organization capable of bringing sustainable security to the region. ${ }^{9}$ This belief is founded upon the conviction that local (Muslim) politicians having control over substantial coercive resources too often have acted in a corrupted and authoritarian manner. Next, these linkages to and support of the 'core MILF' can be explained by a disappointment in, and distrust of, formal state-security institutions. However, when looking specifically at the Midsayap case, this positioning of the core MILF leadership as providing security in tandem with a set of csos needs to be situated within the wider attempt by the MILF to profile itself as a credible and socially legitimate governance alternative. This alternative needs to be set against the backdrop of violent and exploitative clan politics that totally destabilized this municipality - and many othersthroughout the eighties and nineties. Importantly, apart from some specific attempts to improve the physical security of the residents of Midsayap, over the past 10 to 15 years a range of initiatives has also been implemented with a clear objective of redistributing wealth. Often, these initiatives have been organized in collaboration with religious leaders and institutions. One notable example concerns the collection of taxes. As mentioned, the height of warlord politics in Midsayap was characterized by high levels of extortion. At a certain point, the MILF attempted, and ultimately managed, to put a halt to these practices. In fact, mechanisms were deliberately set up to allow people to air their grievances when they felt that they were being the victims of extortion by certain politicians. This mechanism was understood as a crucial 'bumper' to protect civilians. ${ }^{10}$ It was complemented by the establishment of an alternative taxation system, which was set up by the MILF in coordination with religious leaders. A traditional Muslim institution such as the zakat was hereby revived and collected through MILF-appointed tax collectors. One of the purposes of this zakat money was to reinforce the financial capacity of the MILF. However, just as important was the fact that this zakat money also served different social purposes, such as providing financial support for the elderly and widows, or to help students pay tuition fees. This gradual transformation from extortion to redistribution has become an important symbolic reference point for many people in Midsayap, and has clearly added to the popularity and legitimacy of the MILF as a credible governance institution.

9 FGD UNYPAD leadership, 7-2-2014, Cotabato City.

10 Interviews with Maks Mangadta, MINHRAC member, 28-1-2014, Cotabato City, and with Anwar Saluwang, UNYPAD member, 31-1-2014, Cotabato City. 
A last thing that should be said in this regard is the importance of these religious institutions, through which many of these activities were organized. Based on a range of informal interactions and formal interviews with this group, which can be labelled as csos within the orbit of the MILF, we wish to draw attention to two important recurrent features which seem to be widely shared. First, their societal engagement with the MILF was one that was based on a critical assessment of the socio-political landscape within Muslim Mindanao. There is the obvious issue of the clan-based character of politics and the manner in which a limited number of elite clans manage to monopolize political power in the region. This 'internal' critique on power imbalances within Muslim society is often linked to a more classic, 'external' critique on 'imperial Manila'. Simply put, this sort of divisive and corrupted clan politics is understood as an extension of national politics wherein these politicians are integrated in patronage networks tying them to the capital and national political parties. In the meantime, these practices are understood as dividing a unified Bangsamoro political project. The case par excellence that proves this point is the Ampatuan clan, whose creation was understood by many to be the product of a deliberate divide-and-rule strategy by Manila and which is actively supported by national political elites for their own benefit (Human Rights Watch 2010; Rood 2012). Not coincidentally, the Ampatuan clan was also considered to be among the most vocal and fierce opponents of the MILF.

All this can be understood as a confirmation of the generally accepted view that political life in Muslim Mindanao still revolves very much around the institution of the clan. On the other hand, these observations also point to a great deal of dissatisfaction among different sections of Muslim society about the way in which elite-based clan structures are being reproduced. While this may seem evident at first sight, this is a crucial observation that has not always been taken into account in much of the literature on Muslim Mindanao. In much of this literature, there has been an explicit focus on a limited selection of prominent clans that are considered to be the kingmakers in the socio-political landscape. The (often implicit) assumption here is that politics in Muslim Mindanao is very much elite-driven and therefore one needs, above all, to study these elites. Yet, this explicit focus on elites/prominent clans risks grossly underestimating the political agency of the majority of the population in Muslim Mindanao. In other words, the clan as an institution is prominent, but this should not divert our attention away from the very wide dissatisfaction and unease surrounding this institution. For the many people in Muslim Mindanao that do not belong to a powerful clan, the clan is often perceived as an oppressive institution with some very authoritarian features. 
This brings us to our second point, and this concerns the role of these religious institutions and authorities, which were actively deployed by the MILF. Importantly, religion - and more specifically an ideal of equality within Islam - has become one of the prime spheres within which this dissatisfaction with clan politics is being voiced. This was well expressed by a female civilsociety activist engaged in reconciliation interventions, while defending her 'covert' and peaceful engagement with the MILF. As she argued,

actually in Islam, [...] it's not about whether you're from royal blood, from blue blood or green blood, there is no high class, no low class. As long you're practising Islam, then, that's who possesses royal blood. Those who are educated in Islam don't think: 'Oh, I'm the good one, because I'm from royal blood or I'm the good one because I'm the daughter of a datu' - no. If you are Islamized, if you're eligible of religion, then you will erase that idea. You will not claim that you're good. Because me, when I'm educated already, I don't have to say I'm from royal blood just to gain respectno. Because when I'm practising my beliefs, practising Islam, I've already gained respect. I didn't ask for it.11

In short, for this group of activists, religion/Islam - much more than any other ideological framework (for instance, nationalism, liberalism, communism, or socialism) — has become a venue, a space, even a particular language through which a political critique is being articulated. It is only against the background of this critique that we can understand their specific engagement with an organization such as the MILF.

\section{Conclusion}

This article started with the observation that in the past 10 to 15 years, important new insights have been gained about the nature of violence in Muslim Mindanao. These new insights provide a powerful critique of the classic, grievancebased analysis of 'the conflict' in Mindanao as one of a Muslim minority fighting for independence/autonomy in the Christian-dominated Philippine nation-state. Instead, this literature points to the wide range of coercive organizations active in the region and the diffuse and sub-national origins of much

11 FGD, Quick Response team, MWDECC members, 21-9-2014, Cotabato City. Please note that this is a literal transcription of the interview. 
of the violence. Despite having multiple merits, it has been argued that there is a tendency within this literature to reduce the conflict landscape to one that is simply driven by greed. In addition, public authority is too often simplified as just being rooted in exploitative and coercive clientelistic relationships. As we have argued, this analysis is too narrow to explain the remarkable growth of the MILF during the past decades.

As an alternative, we have attempted to bring grievances back into the analysis by indicating how the growth of the MILF needs to be situated within a critical reading of the socio-political landscape within Muslim Mindanao. It is worth noting that for many MILF sympathizers and civil-society activists, the systematic reproduction of unequal power relations in their own locality is intimately tied to the workings of the larger national body politic, which is considered to be corrupted and which nurtures local elites who preside over these quasi-totalitarian enclaves. It is also against this background that the specific religious ideology of the MILF needs to be understood. This religious ideology serves as an ideal of equality which is opposed to a corrupted and feudal socio-political landscape.

The manner in which 'the MILF' opposes these local strongmen is often ambiguous. As extensively shown throughout this article, the label MILF covers a wide range of organizations, members, identities, and rationalities. In a socio-political landscape in which the clan remains an important social institution bridging state and society, it seems that the MILF has followed a policy of slow and gradual incorporation rather than a brutal confrontation with these clans. As such, a nuanced picture emerges wherein local political strongmen, in some cases with highly authoritarian and undemocratic credentials, identify as MILF. It is also clear that these local strongmen display a great deal of autonomy against the central political leadership. Therefore, it is crucial not to portray and approach the MILF as a homogeneous group, but to pay attention to the different fault lines, cleavages, and sometimes contrasting political objectives which all reside within or revolve around this one organization. Despite this complexity, based on our data, we have distinguished three major social fields within the MILF: 1) a central leadership, referred to as 'core MILF'; 2) a variety of local powerholders/local commanders who display varying degrees of allegiance to this core MILF; and 3) a coalition of Csos. The main characteristic of this last group is that it consists of ordinary, unarmed citizens playing no direct role in the military organization of the MILF. These ordinary citizens can both be formal members of the MILF or people/organizations working in the orbit of the MILF.

When studying the interaction between these social fields, three important things stand out. First, based on an analysis of the recent history of the munic- 
ipality of Midsayap, North Cotabato, it is clear that the core MILF has managed to obtain increasing control over a range of local political leaders. Increasingly, a system of sanctioning has been implemented wherein these local politicians/commanders are threatened to be taken into custody by this core MILF when not following some specific policies. Evidently, the implementation of a range of state-sanctioned mechanisms to curb violence and criminality and wherein the MILF plays a central role has added to the capacity of this core MILF. Equally important, however, is that this increase in coercive capacity went hand in hand with deliberate attempts by the MILF to present themselves as a sincere and legitimate alternative to a type of warlord politics that was violent, exploitative, authoritarian, and, therefore, unpopular and unsustainable. As part of these efforts, the setting up of a wide network of Muslim csos has been crucial. This network of MILF-aligned csos shares the negative assessment of the type of warlord politics that existed, which, in their view, hindered any true political and economic development of the region. Based on this frustration, this network sees a credible governance alternative in the MILF that they wish to support in a variety of non-violent ways. Much more than might be initially accounted for, this type of civil support has been crucial in a number of governance arena's and therefore in the growth of the MILF as a legitimate civil organization. One specific example that has been discussed is the role this network plays in conflict management and third-party-mediation initiatives. Within this article, we have empirically illustrated this by providing an analysis of the mediation of one specific dispute in the village of Gayonga. Other attempts at mediation in the region have been studied in recent years wherein a similar dynamic could be observed. Simply put, this network of 'organic members' has been pivotal in establishing a venue through which disputing clans could communicate with each other to find a solution for their violent disputes. It is also exactly here that the limits of the MILF as a mere rebel group become visible. As local MILF commanders also display a great deal of allegiance to their clans, the MILF inevitably becomes dragged into this fractionalized landscape. Hence, the legitimacy to mediate as a neutral third party is heavily reduced. It is exactly at this point that a crucial tactical alliance emerged between the core MILF and a network of affiliated csos. This brings us to our last point. This article depicts the MILF as being much more than just an armed rebel group. Much of the literature on political developments in Muslim Mindanao has focused on the actual motives and/or immediate causes of violence in the region. As a result, our understanding of an organization such as the MILF has been highly distorted and biased, as this organization has mainly been approached as just another armed group. Our analysis has shown how this is not the right approach by illustrating how a group of organi- 
zations/people, who clearly are not hardened fighters, has nevertheless played an essential role in the development of this organization and, ultimately, in the struggle for an autonomous Bangsamoro. The political agency of these subaltern populations and organizations has been fundamental for the development and the growth of the MILF, not only as an oppositional alternative to 'imperial Manila' but also as an oppositional alternative to local, clan-based elites.

\section{References}

Abinales, Patricio N. (200o). Making Mindanao. Cotabato and Davao in the formation of the Philippine nation-state. Manila: Ateneo de Manila University Press.

Abinales, Patricio N. (2010). Orthodoxy and history in the Muslim-Mindanao narrative. Manila: Ateneo de Manila University Press.

Abuza, Z. (2005). 'The Moro Islamic Liberation Front at 20: State of the revolution', Studies in Conflict and Terrorism 28:453-79.

Adam, Jeroen (2013). 'A comparative analysis of the micro-level genealogies of conflict in the Philippines' Mindanao Island and Indonesia's Ambon Island', Oxford Development Studies 41-2:155-72.

Anderson, Benedict (1988). 'Cacique democracy in the Philippines. Origins and dreams', New Left Review 169:3-33.

Bertrand, Jacques (2000). 'Peace and conflict in the southern Philippines: Why the 1996 Peace Agreement is fragile', Pacific Affairs 73-1:37-54.

Cabrera, F.B. (2014). 'MILF commander, village chief son killed in ambush by rival rebel commander in Maguindanao', Mindanews, 21 August 2014. Available at www .mindanews.com/top-stories/2014/o8/21/milf-commander-village-chief-son-killed -in-ambush-by-rival-rebel-commander-in-maguindanao/ (accessed 22 December 2016).

Che Man, W.K. (1990). Muslim separatism. The Moros of the southern Philippines and the Malays of Thailand. Oxford: Oxford University Press.

Human Rights Watch (2010). They own the people. The Ampatuans, state-backed militias, and killings in the southern Philippines. New York: Human Rights Watch.

International Alert (2014). Rebellion, political violence and shadow crimes in the Bangsamoro. The Bangsamoro Conflict Monitoring System (BCMS), 2011-2013. Washington: The World Bank.

Jubair, S. (1999). Bangsamoro. A nation under endless tyranny. Kuala Lumpur: IQ Marin SDN BHD.

Jubair, S. (2007). The long road to peace. Inside the GRP-MILF peace process. Cotabato: Institute of Bangsamoro Studies. 
Kreuzer, Peter (2005). Political clans and violence in the Philippines. Frankfurt: Peace Research Institute Frankfurt (PRIF). [Report no. 71.]

Lara, Francisco J. (2014). Insurgents, clans, and states. Political legitimacy and resurgent conflict in Muslim Mindanao, Philippines. Manila: Ateneo de Manila University Press.

Lara, Francisco J. and Champain P. (2009). Inclusive peace in Muslim Mindanao: Revisiting the dynamics of conflict and exclusion. London: International Alert.

Mastura, Michael (2012). Bangsamoro quest. The birth of the Moro Islamic Liberation Front. Kuala Lumpur: Southeast Asian Conflict Studies Network (SEACSN).

Mc Kenna, Tomas M. (1998). Muslim rulers and rebels: Everyday politics and armed separatism in the southern Philippines. Berkeley: University of California Press.

Podder, S. (2012). 'Legitimacy, loyalty and civilian support for the Moro Islamic Liberation Front: Changing dynamics in Mindanao, Philippines', Politics, Religion \& Ideology 13-4:495-512.

Quimpo, N.G. (2005). 'Review: Oligarchic patrimonialism, bossism, electoral clientelism, and contested democracy in the Philippines', Comparative Politics 37-2:229$5^{\circ}$.

Rood, S. (2012). 'Interlocking autonomy: Manila and Muslim Mindanao', in: Michelle Miller (ed.) Autonomy and armed separatism in South and Southeast Asia, pp. 25677. Singapore: ISEAS (Institute for Southeast Asian Studies).

Sidel, J. (1999). Capital, coercion and crime. Bossism in the Philippines. Stanford: Stanford University Press.

Taya, S.L. (2007). 'The political strategies of the Moro Islamic Liberation Front for selfdetermination in the Philippines', Intellectual Discourse 15-1:59-84.

The Asia Foundation (2010). 'Mitigating conflicts in barangay Gayonga, northern Kabuntalan, Maguindanao. Final narrative report'. [Unpublished paper.]

Torres W.M. (ed.) (2007). Rido. Clan feuding and conflict management in Mindanao. Manila: The Asia Foundation.

Tuminez, Astrid (2007). 'This land is our land. Moro ancestral domain and its implications for peace and development in the southern Philippines', The sAIs Review of International Affairs 27-2:77-91.

Unson, J. (2014). 'Military on alert for brewing conflict between 2 MILF factions', Philstar, 5 August 2014. Available at http://www.philstar.com/nation/2014/o8/o5/ 1354134/military-alert-brewing-conflict-between-2-milf-factions (accessed 22 December 2016).

Verbrugge, Boris and Adam, J. (2016). 'Questioning the state-rebel divide in Mindanao? A comparative analysis of North Cotabato and Compostela Valley province', Asian Journal of Social Science 44-1:247-87. 